\title{
How should nonspecific complaints be defined? Comment to: "nonspecific complaints (NSCs) in the emergency department"
}

\author{
Roland Bingisser ${ }^{*}$ and Christian H. Nickel
}

\section{Dear Editor,}

With great interest we have read the recent systematic review on "Nonspecific Complaints (NSCs) in the Emergency Department" [1] and would like to comment on two key aspects: First, we agree that NSCs should be considered a major emergency presentation. Different nomenclatures have been used in the past, such as "homecare impossible", "unexplained symptoms", "general disability", "atypical symptoms", and "nonspecific functional decline" (for review, see [2]). This diversity has not been helpful for a clinical definition or clinical research on nonspecific complaints [3]. Second, the authors did not present any definition of nonspecific complaints, but included studies using varying definitions from very different settings, such as Emergency Medical Services (EMS).

However, NSCs were first defined by Nemec et al [4] This original definition was based on the inclusion of patients in need of external resources, excluding patients with life-saving interventions. The original BANC studies excluded hemodynamically unstable patients (i.e. Emergency Severity Index (ESI) level 1; patients in need of life-saving interventions), as the work-up of shock is standardized. Similarly, the lowest triage categories were excluded as well, as these patients can usually be managed as see-and-treat outpatients and are not at risk for adverse outcomes. The rationale to focus on these patients is the lack of a standardized work-up, the high use of resources, and the risk of adverse outcomes [5-8]. All publications originating from the prospective multicenter Basel Nonspecific Complaints (BANC) cohorts used the above definition of NSCs [9-12], but other studies have used varying criteria to define NSCs [13]. There is an inherent difference regarding inclusion criteria between the studies considered by the present systematic review, e.g., some of the included studies were retrospective, and one study [14] has used a post-hoc classification of nonspecific complaints [15].

Surprisingly, the original publication by Nemec et al. [4], coining the term, was excluded from the present systematic review. We believe that this was based on arbitrary inclusion criteria. The argument to exclude studies deliberately focusing on certain triage categories does not seem valid unless an alternative, stringent definition of NSCs is used.

Therefore, we suggest that further research should be based on a common definition of nonspecific complaints in emergency presentations, in order to reduce heterogeneity of studies.

\section{Abbreviations \\ NSCs: Nonspecific complaints; BANC study: Basel nonspecific complaints study; ESI: Emergency severity index}

\section{Acknowledgments}

NA

\section{Authors' contributions}

The author(s) read and approved the final manuscript.

\footnotetext{
* Correspondence: roland.bingisser@usb.ch

Emergency Department, University Hospital Basel, University of Basel,

Petersgraben 2, $\mathrm{CH}-4031$ Basel, Switzerland
}

(c) The Author(s). 2020 Open Access This article is licensed under a Creative Commons Attribution 4.0 International License, which permits use, sharing, adaptation, distribution and reproduction in any medium or format, as long as you give appropriate credit to the original author(s) and the source, provide a link to the Creative Commons licence, and indicate if changes were made. The images or other third party material in this article are included in the article's Creative Commons licence, unless indicated otherwise in a credit line to the material. If material is not included in the article's Creative Commons licence and your intended use is not permitted by statutory regulation or exceeds the permitted use, you will need to obtain permission directly from the copyright holder. To view a copy of this licence, visit http://creativecommons.org/licenses/by/4.0/ The Creative Commons Public Domain Dedication waiver (http://creativecommons.org/publicdomain/zero/1.0/) applies to the data made available in this article, unless otherwise stated in a credit line to the data. 


\section{Author's information}

Both authors are on twitter: @EDbingi, @replynickel.

\section{Availability of data and materials \\ NA}

\section{Ethics approval and consent to participate}

NA

\section{Consent for publication}

NA

\section{Competing interests}

We perform symptom-oriented research and are editors of www.medstandards.com

Received: 17 September 2020 Accepted: 28 October 2020

Published online: 11 November 2020

\section{References}

1. Kemp K, Mertanen R, Lääperi M, Niemi-Murola L, Lehtonen L, Castren M. Nonspecific complaints in the emergency department - a systematic review. Scand J Trauma Resusc Emerg Med. 2020;28(1):6

2. Bingisser $\mathrm{R}$, Nickel $\mathrm{CH}$. The last century of symptom-oriented research in emergency presentations--have we made any progress? Swiss Med Wkly. 2013;143:w13829.

3. Nickel $\mathrm{CH}$, Malinovska A, Bingisser R. Should weakness be subsumed to nonspecific complaints?-correspondence in response to Bhalla et al. Am J Emerg Med. 2015;33(5):722-3.

4. Nemec M, Koller MT, Nickel CH, Maile S, Winterhalder C, Karrer C, Laifer G, Bingisser R. Patients presenting to the emergency department with nonspecific complaints: the Basel non-specific complaints (BANC) study. Acad Emerg Med. 2010;17(3):284-92.

5. Nickel CH, Messmer AS, Geigy N, Misch F, Mueller B, Dusemund F, Hertel S, Hartmann O, Giersdorf S, Bingisser R. Stress markers predict mortality in patients with nonspecific complaints presenting to the emergency department and may be a useful risk stratification tool to support disposition planning. Acad Emerg Med. 2013;20(7):670-9.

6. Nickel $\mathrm{CH}$, Ruedinger JM, Messmer AS, Maile S, Peng A, Bodmer M, Kressig RW, Kraehenbuehl S, Bingisser R. Drug-related emergency department visits by elderly patients presenting with non-specific complaints. Scand J Trauma Resusc Emerg Med. 2013;21:15.

7. Peng A, Rohacek M, Ackermann S, Ilsemann-Karakoumis J, Ghanim L, Messmer AS, Misch F, Nickel CH, Bingisser R. The proportion of correct diagnoses is low in emergency patients with nonspecific complaints presenting to the emergency department. Swiss Med Wkly. 2015;145: W14121.

8. Nickel $\mathrm{CH}$, Ruedinger J, Misch F, Blume K, Maile S, Schulte J, Köhrle J, Hartmann O, Giersdorf S, Bingisser R. Copeptin and peroxiredoxin-4 independently predict mortality in patients with nonspecific complaints presenting to the emergency department. Acad Emerg Med. 2011;18(8): 851-9.

9. Karakoumis J, Nickel CH, Kirsch M, Rohacek M, Geigy N, Müller B, Ackermann S, Bingisser R. Emergency presentations with nonspecific complaints-the burden of morbidity and the Spectrum of underlying disease: nonspecific complaints and underlying disease. Medicine (Baltimore). 2015;94(26):e840

10. Jenny MA, Hertwig R, Ackermann S, Messmer AS, Karakoumis J, Nickel CH, Bingisser R. Are mortality and acute morbidity in patients presenting with nonspecific complaints predictable using routine variables? Acad Emerg Med. 2015;22(10):1155-63.

11. Malinovska A, Nickel $\mathrm{CH}$, Bingisser R. Trajectories of survival in patients with nonspecific complaints. Eur J Intern Med. 2018;55:e17-8.

12. Nickel $\mathrm{CH}$, Messmer AS, Ghanim L, Ilsemann-Karakoumis J, Giersdorf S, Hertel S, Ernst S, Geigy N, Bingisser R. Adrenomedullin for risk stratification of emergency patients with nonspecific complaints: an interventional multicenter pilot study. Medicine (Baltimore). 2016;95(1):e2395.

13. Quinn K, Herman M, Lin D, Supapol W, Worster A. Common diagnoses and outcomes in elderly patients who present to the emergency department with non-specific complaints. Cjem. 2015;17(5):516-22.

14. Sauter TC, Capaldo G, Hoffmann M, Birrenbach T, Hautz SC, Kämmer JE, Exadaktylos AK, Hautz WE. Non-specific complaints at emergency department presentation result in unclear diagnoses and lengthened hospitalization: a prospective observational study. Scand J Trauma Resusc Emerg Med. 2018;26(1):60.

15. Bingisser R, Nickel $\mathrm{CH}$. Comment to: non-specific complaints at emergencydepartment presentation result in uncleardiagnoses and lengthened hospitalization: a prospective observational study. Scand J Trauma Resusc Emerg Med. 2018;26(1):99.

\section{Publisher's Note}

Springer Nature remains neutral with regard to jurisdictional claims in published maps and institutional affiliations.
Ready to submit your research? Choose BMC and benefit from:

- fast, convenient online submission

- thorough peer review by experienced researchers in your field

- rapid publication on acceptance

- support for research data, including large and complex data types

- gold Open Access which fosters wider collaboration and increased citations

- maximum visibility for your research: over $100 \mathrm{M}$ website views per year

At $\mathrm{BMC}$, research is always in progress.

Learn more biomedcentral.com/submissions 